\title{
COVERAGE OF INTERMOLECULAR FORCES IN ORGANIC CHEMISTRY TEXTBOOKS
}

\author{
José Nunes da Silva Júnior, ${ }^{\mathrm{a}, *,(\mathbb{C})}$ José Mariano de Sousa Oliveira, ${ }^{a}$ Francisco Serra Oliveira Alexandre ${ }^{\mathrm{b}}$ and Antonio José \\ Mello Leite Junior ${ }^{\mathrm{c}}$ \\ a'Departamento de Química Orgânica e Inorgânica, Universidade Federal do Ceará, 60451-970 Fortaleza - CE, Brasil \\ 'Instituto Federal de Educação, Ciência e Tecnologia do Ceará, 60040-215 Fortaleza - CE, Brasil \\ 'UFC Virtual, Universidade Federal do Ceará, 60451-970 Fortaleza - CE, Brasil
}

Recebido em 19/03/2021; aceito em 12/04/2021; publicado na web em 12/05/2021

\begin{abstract}
The paper analyzes fifteen organic chemistry textbooks commonly used in Brazilian universities to examine intermolecular forces' coverage in them. The findings revealed that the intermolecular forces are spread over a few pages (less than 1\%) in a fragmented way, and over several chapters that do not provide enough information to help create a clear image in the student's mind. Thirteen textbooks contained end-of-chapter problems related to intermolecular forces. However, less than 1.3\% of the total (212) are associated with intermolecular forces. This deficient approach to intermolecular forces in Organic textbooks can lead to teachers' lack of interest in teaching the subject, leading to students failing to learn this important organic chemistry topic.
\end{abstract}

Keywords: intermolecular forces; organic chemistry; textbooks.

\section{INTRODUCTION}

Intermolecular forces (IMFs) are weak attractive forces used to explain the attraction between particulate matter. They are responsible for many phenomena in our lives, like the effects of adsorption (chromatography) and viscosity, adhesion, cohesion, differences in melting and boiling points, physical states of the compounds, solubility, among many other observations.

The mastery of intermolecular forces is crucial to chemistry students because the IMFs play a central role in predicting and explaining how molecular-level systems behave in chemical and biological systems. Thus, the importance and diversity of IMFs make them a valuable component of curricula in chemistry, biochemistry, and biology courses.

Unfortunately, authors have reported students' difficulties understanding the concepts of particulate matter and the intermolecular forces. ${ }^{1-17}$ Also, students have problems understanding how molecules are held together without chemical bonds between them, ${ }^{1,2}$ melting and boiling processes, ${ }^{7,8}$ and rarely can draw and explain the types of IMFs between chemical species. ${ }^{9,10}$

Although study guides, solution manuals, websites, and applications are increasingly used as complementary educational tools by instructors in their disciplines, textbooks still play a vital role in determining course curricula, both in specific content and pedagogical approaches.

Dense courses like Chemistry, a content-filled subject, make most instructors derive their course material directly from textbooks by considering their coverage and presenting the contents. ${ }^{18}$ The best option will be that one that motivates students to spend the highest time interacting with the book.

This study analyzes organic chemistry textbooks to determine common patterns and assess how they introduce the intermolecular forces' contents. Moreover, the manuscript's information can help organic chemistry instructors choice about adopting an organic chemistry textbook considering the IMFs content.

\section{BACKGROUND}

\section{Professors' opinions}

In over two decades of teaching intermolecular forces in organic chemistry courses in Brazilian Universities, we considered this subject poorly presented in the textbooks. That made it difficult for us to explore that subject properly. To investigate whether this is a personal complaint or if other colleagues shared this same dissatisfaction, we invited Brazilian and French professors to answer an electronic form with problems on the topic.

We asked professors two main questions:

i) Do you consider the intermolecular forces an important content in organic chemistry?

ii) How do you evaluate the way how textbooks present the intermolecular forces?

One hundred and eleven Brazilian (from twenty-five universities) $)^{19}$ and twenty French professors (from six French universities ${ }^{20}$ answered the electronic form, and the results are in Table 1.

Table 1. Brazilian and French professors' evaluations of the content of intermolecular forces in the organic chemistry textbooks

\begin{tabular}{lcc}
\hline Rating & $\begin{array}{c}\text { Brazilian }(\%) \\
(\mathrm{N}=111)\end{array}$ & $\begin{array}{c}\text { French }(\%) \\
(\mathrm{N}=20)\end{array}$ \\
\hline Excellent & 1.80 & 0.00 \\
Good & 31.53 & 20.00 \\
Average & 51.35 & 50.00 \\
Bad & 13.51 & 25.00 \\
Awful & 1.81 & 5.00 \\
\hline
\end{tabular}

All professors considered the intermolecular forces an important subject in organic chemistry. However, only $66.67 \%$ of the Brazilian professors and $80.00 \%$ of the French professors considered average/bad/awful how the organic chemistry textbooks present the intermolecular forces. The survey's results motivated us to investigate the IMFs in more detail in widely adopted organic chemistry textbooks in Brazil. 


\section{ORGANIC CHEMISTRY TEXTBOOKS}

We analyzed fifteen organic chemistry textbooks (Table 2) currently used by Brazillian professors to prepare their lectures.

Although all analyzed textbooks present intermolecular forces, the examination of Table 1 revealed that they do that in a small number of pages ( $0.9 \%$ on average). Besides, topics related to intermolecular forces are spread over several chapters (4.8 on average) in all books, with no specific chapter to address the theme. This weak approach to intermolecular forces in textbooks can lead to teachers' lack of interest in teaching the subject, failing to learn this vital organic chemistry topic.

\section{COVERAGE OF TOPICS RELATED TO INTERMOLECULAR FORCES}

We have also surveyed the organic chemistry textbooks currently used in Brazilian universities to reveal which topics related to the intermolecular forces are included in them. We analyzed 34 issues distributed in five categories: i) types; ii) physical properties; iii) biomolecules; iv) analytical techniques; and (v) other. Tables 3-8 summarize the results of the search.

\section{Types of intermolecular forces}

Table 4's data reveals that textbooks introduce five types of intermolecular forces (hydrogen bonds; London forces; dipole-dipole; ion-dipole, and dipole-induced dipole) in different ways.

$86.7 \%$ of the books present hydrogen bonding and provide examples. However, $13.3 \%$ of them only offer examples of this type of interaction but do not explain it. $80.0 \%$ of the books present the London forces. While $80 \%$ of the books explain and provide examples of London forces, $6.7 \%$ of the books only introduce the dipole-dipole interactions by giving examples, and no explanation is given.

$93.3 \%$ of the books present the ion-dipole interactions. However, only $40 \%$ of the books explain and provide examples of this type of interaction, while $53.3 \%$ show examples to introduce the interaction with no explanation.
Only $13.4 \%$ of the books present the dipole-induced dipole interaction, while the ion-induced dipole interaction is not present in any book.

\section{Physical properties}

Physical properties are closely related to organic compounds' physical properties; however, organic chemistry textbooks present (or not) them in very different ways (Table 5). Melting point, boiling point, and solubility are the physical properties presented in most books: $93.3 \%, 93.3 \%$, and $100.0 \%$, respectively. These physical properties are explained with examples, figures, and graphs and are usually introduced in those chapters which present the functional groups.

Density is a topic present in $60 \%$ of the books. However, only $40 \%$ of the books explain this property and provide examples. In $20 \%$ of the books, density is mentioned without defining its relationship with the intermolecular forces.

Other physical properties, such as vapor pressure, surface tension, adhesion-cohesion, capillarity, and viscosity, are not mentioned in at least $80.0 \%$ of the books surveyed. Besides, in none of the cases, the books explain the relationship between these properties and the intermolecular forces neither provide any examples. Some textbooks introduce those physical properties (except adhesion-cohesion) through examples, but no explanation is given.

\section{Biomolecules}

Biomolecules are closely related to the intermolecular forces. IMFs are responsible for attractive forces between the biomolecules and other 3D structures like DNA, proteins, and drugs. Table 6 shows that at least $80.0 \%$ of the books present all seven biomolecules by relating them to IMFs in different ways. Besides, $86.7 \%$ of the books introduce interactions between drugs and receptors; however, $20.0 \%$ of this total only present examples of interactions between drugs and receptors but do not explain the intermolecular forces' action. The same takes place with four other biomolecules in $6.7 \%$ of the books.

Table 2. Comparison of total of pages, number of pages on IMFs, number of chapters covering any topic related to the IMFs, and number of problems related to the IMFs in organic chemistry surveyed

\begin{tabular}{|c|c|c|c|c|c|c|c|c|}
\hline Author & Publisher & Edition & $\begin{array}{l}\text { Total } \\
\text { Pages }\end{array}$ & $\begin{array}{c}\text { Total } \\
\text { Problems }\end{array}$ & $\begin{array}{l}\text { IMFs } \\
\text { Pages }^{\text {a }}\end{array}$ & $\begin{array}{l}\text { IMFs } \\
\text { Topics }^{\text {b }}\end{array}$ & $\begin{array}{c}\text { IMFs } \\
\text { Chapters }^{\mathrm{c}}\end{array}$ & $\begin{array}{c}\text { IMFs } \\
\text { Problems }\end{array}$ \\
\hline Brown, W. H. ${ }^{21}$ & Cengage & $6^{\text {th }}$ & 1194 & 1463 & 14 & 9 & 12 & 44 \\
\hline Bruice, P. Y. ${ }^{22}$ & Pearson & $7^{\text {th }}$ & 1293 & 1918 & 14 & 11 & 6 & 21 \\
\hline Carey, F. A..$^{23}$ & McGraw-Hill & $7^{\text {th }}$ & 1229 & 1435 & 17 & 7 & 12 & 09 \\
\hline Clayden, J. ${ }^{24}$ & Oxford & $1^{\mathrm{st}}$ & 1512 & 585 & 7 & 5 & 5 & 00 \\
\hline Hoffmann, R. V. ${ }^{25}$ & Wiley & $2^{\text {nd }}$ & 476 & 94 & 1 & 1 & 1 & 00 \\
\hline Jones Jr., M. ${ }^{26}$ & W. W. Norton & $4^{\text {nd }}$ & 1220 & 1467 & 3 & 3 & 1 & 04 \\
\hline Klein, D..$^{27}$ & Wiley & $1^{\mathrm{st}}$ & 1295 & 1895 & 11 & 6 & 2 & 11 \\
\hline Loundon, G. M. ${ }^{28}$ & W. H. Freeman & $6^{\text {th }}$ & 1485 & 1837 & 28 & 5 & 2 & 32 \\
\hline McMurry, J. ${ }^{29}$ & Cengage & $8^{\text {th }}$ & 1262 & 1842 & 5 & 4 & 3 & 03 \\
\hline McMurry, $\mathrm{J}^{30}$ & Cengage & $2^{\text {nd }}$ & 1044 & 1384 & 5 & 6 & 3 & 03 \\
\hline Smith, J. G. ${ }^{31}$ & McGraw-Hill & $3^{\text {rd }}$ & 1178 & 2149 & 25 & 14 & 8 & 51 \\
\hline Solomons, T. W. G. ${ }^{32}$ & Wiley & $10^{\text {th }}$ & 1164 & 1266 & 9 & 9 & 1 & 12 \\
\hline Stowell, J. C. ${ }^{33}$ & Wiley & $3^{\text {rd }}$ & 335 & 230 & 1 & 1 & 1 & 01 \\
\hline Vollhardt, $\mathrm{P}^{34}$ & W. H. Freeman & $6^{\text {th }}$ & 1270 & 1702 & 14 & 8 & 9 & 06 \\
\hline Wade Jr., L. G. ${ }^{35}$ & Pearson & $6^{\text {th }}$ & 1262 & 1417 & 14 & 4 & 6 & 15 \\
\hline
\end{tabular}

${ }^{a}$ Number of pages related to IMFs ${ }^{b}$ Number of topics related to IMFs ${ }^{c}$ Number of chapters covering any topic related to the IMFs ${ }^{d}$ Number of problems related to the IMFs. 
Table 3. Distribution of intermolecular forces topics coverage in surveyed organic chemistry textbooks

\begin{tabular}{|c|c|c|c|c|c|c|c|c|c|c|c|c|c|c|c|c|}
\hline \multirow[b]{2}{*}{ Category } & \multirow[b]{2}{*}{ Topics } & \multicolumn{15}{|c|}{ Textbooks } \\
\hline & & 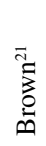 & 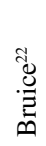 & 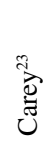 & 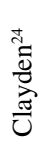 & 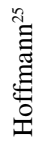 & 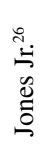 & $\frac{\bar{a}}{\overrightarrow{0}}$ & 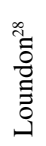 & 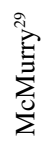 & 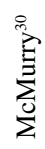 & 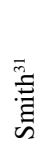 & 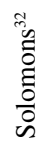 & $\begin{array}{l}\frac{\tilde{n}}{0} \\
\frac{\tilde{D}}{0} \\
\frac{0}{n}\end{array}$ & 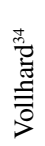 & 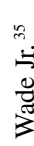 \\
\hline \multirow{6}{*}{ Types } & London forces & $\mathrm{A}$ & A & A & 0 & 0 & A & A & A & A & A & A & A & 0 & $\mathrm{~A}$ & A \\
\hline & Dipole-dipole & A & A & A & 0 & 0 & B & A & A & A & A & A & A & 0 & A & A \\
\hline & Hydrogen bonding & A & A & A & A & B & A & A & A & A & A & A & A & B & A & $\mathrm{A}$ \\
\hline & Dipole-induced dipole & 0 & 0 & A & 0 & 0 & 0 & 0 & B & 0 & 0 & 0 & 0 & 0 & 0 & 0 \\
\hline & Ion-dipole & B & A & A & B & B & B & B & A & B & 0 & A & A & B & A & B \\
\hline & Ion-induced dipole & 0 & 0 & 0 & 0 & 0 & 0 & 0 & 0 & 0 & 0 & 0 & 0 & 0 & 0 & 0 \\
\hline \multirow{12}{*}{ Physical proprieties } & Boiling point & A & A & A & B & B & A & A & A & A & A & A & A & 0 & A & A \\
\hline & Melting point & A & A & A & B & B & A & A & A & A & A & A & A & 0 & A & A \\
\hline & Solubility & A & A & A & B & B & A & A & A & A & $\mathrm{B}$ & A & A & $\mathrm{B}$ & A & A \\
\hline & Density & A & 0 & B & 0 & 0 & B & 0 & A & B & 0 & A & A & 0 & A & A \\
\hline & Meniscus and drop format & 0 & 0 & 0 & 0 & 0 & 0 & 0 & 0 & 0 & 0 & 0 & 0 & 0 & 0 & A \\
\hline & Vapour pressure & $\mathrm{B}$ & 0 & 0 & 0 & B & 0 & 0 & 0 & 0 & 0 & 0 & 0 & 0 & $\mathrm{~B}$ & 0 \\
\hline & Dyes and dyeing & B & 0 & 0 & B & 0 & 0 & 0 & B & 0 & 0 & A & A & 0 & $\mathrm{~B}$ & B \\
\hline & Salting-out effect & 0 & 0 & 0 & 0 & 0 & 0 & 0 & 0 & 0 & 0 & 0 & 0 & 0 & 0 & 0 \\
\hline & Surface tension & 0 & 0 & 0 & 0 & 0 & 0 & 0 & B & 0 & 0 & 0 & 0 & 0 & B & 0 \\
\hline & Adhesion-cohesion & 0 & 0 & 0 & 0 & 0 & 0 & 0 & 0 & 0 & 0 & 0 & 0 & 0 & 0 & 0 \\
\hline & Capilarity & 0 & $\mathrm{~B}$ & 0 & 0 & 0 & 0 & 0 & 0 & 0 & 0 & 0 & 0 & 0 & 0 & 0 \\
\hline & Viscosity & $\mathrm{B}$ & 0 & 0 & 0 & 0 & 0 & 0 & 0 & 0 & 0 & 0 & 0 & 0 & 0 & $\mathrm{~B}$ \\
\hline \multirow{9}{*}{ Biomolecules } & Cellulose and Starch & A & A & A & A & 0 & B & A & A & 0 & A & A & A & 0 & A & A \\
\hline & Carbohydrates & A & A & A & A & 0 & $\mathrm{~B}$ & A & A & A & A & A & A & 0 & A & A \\
\hline & Fatty acids-Soap-Micelles & A & A & A & A & 0 & A & A & A & A & A & A & A & 0 & A & A \\
\hline & Cell membranes & A & A & A & A & 0 & B & A & A & A & A & A & A & 0 & A & A \\
\hline & DNA & A & A & A & A & 0 & A & A & A & A & A & A & A & 0 & A & A \\
\hline & Enzymes & A & A & A & A & B & A & A & A & A & A & A & A & 0 & A & A \\
\hline & Proteins & A & A & A & B & 0 & A & A & A & A & A & A & A & 0 & A & A \\
\hline & Polymers & A & A & A & A & 0 & A & A & B & B & B & A & $\mathrm{B}$ & 0 & A & A \\
\hline & Drugs-receptors & A & A & A & A & 0 & $\mathrm{~A}$ & A & $\mathrm{B}$ & $\mathrm{B}$ & $\mathrm{B}$ & $\mathrm{A}$ & A & 0 & A & $\mathrm{A}$ \\
\hline \multirow{6}{*}{ An. Tech. } & Infrared & A & A & A & A & B & 0 & A & A & A & A & A & A & 0 & A & A \\
\hline & NMR & A & A & A & 0 & 0 & A & 0 & A & 0 & 0 & A & A & 0 & A & A \\
\hline & Paper chromatography & 0 & A & 0 & 0 & 0 & 0 & 0 & B & 0 & 0 & 0 & 0 & 0 & 0 & 0 \\
\hline & Chromatography - TLC & 0 & A & 0 & 0 & 0 & 0 & 0 & 0 & 0 & 0 & 0 & 0 & 0 & 0 & 0 \\
\hline & Chromatography - Column & A & A & A & A & B & A & $\mathrm{C}$ & A & A & A & 0 & A & B & B & A \\
\hline & Electrophoresis & A & A & A & 0 & 0 & A & A & 0 & A & A & 0 & A & 0 & A & A \\
\hline \multirow{2}{*}{ Other } & Graphite & B & B & B & B & 0 & B & A & B & 0 & 0 & A & A & 0 & B & A \\
\hline & Crown ether & A & A & A & A & 0 & A & A & A & A & 0 & A & A & 0 & A & A \\
\hline
\end{tabular}

Notation: A: Topic is explained, and example(s) are provided; B: Topic is not explained, but provide examples; C: Topic is explained, but examples are not provided; 0: Topic is not covered.

\section{Analytical Techniques}

Infrared, nuclear magnetic resonance (NMR), chromatography, and electrophoresis are analytical techniques closely related to the intermolecular forces. For example, in infrared, the $\mathrm{O}-\mathrm{H}$ stretching of alcohol results in broad bands $\left(3200-3550 \mathrm{~cm}^{-1}\right)$ when alcohol bonds intermolecularly to another by hydrogen bonding. The chemical shift of hydrogens bonded to oxygen atoms varies if hydrogen is interacting intermolecularly with the solvent. All chromatographic techniques (paper, column, TLC, electrophoresis, among others) promote the separation of organic compounds based on the different types of attraction forces between the organic compound (in the mobile phase) and the stationary phase.

Table 7 shows that the influence of intermolecular forces on infrared spectra is mentioned in $86.7 \%$ of the textbooks surveyed. In $80.0 \%$ of them, the content is explained by providing examples. In comparison, in $6.7 \%$ of the books, the bandwidth phenomenon is presented by showing examples without any explanation related to the hydrogen bonding.

The intermolecular forces are present in only $60 \%$ of the textbooks 
Table 4. Percentage distribution of coverage on types of intermolecular forces in textbooks

\begin{tabular}{lcccc}
\hline \multirow{2}{*}{ Type of Interactions } & \multicolumn{4}{c}{ Types of Coverage $\mathrm{a}^{\mathrm{a}}$} \\
\cline { 2 - 5 } & $\% \mathrm{~A}$ & $\% \mathrm{~B}$ & $\% \mathrm{C}$ & $\% 0$ \\
\hline Ion-induced dipole & 0.0 & 0.0 & 0.0 & 100.0 \\
Hydrogen bonding & 86.7 & 13.3 & 0.0 & 0.0 \\
London forces & 80.0 & 0.0 & 0.0 & 20.0 \\
Dipole-dipole & 73.3 & 6.7 & 0.0 & 20.0 \\
Ion-dipole & 40.0 & 53.3 & 0.0 & 6.7 \\
Dipole-induced dipole & 6.7 & 6.7 & 0.0 & 86.6 \\
\hline
\end{tabular}

aNotation: A: Topic is explained, and example(s) are provided; B: Topic is not explained, but provide examples; $\mathrm{C}$ : Topic is explained, but examples are not provided; 0: Topic is not covered.

Table 5. Percentage distribution of coverage on physical properties in textbooks

\begin{tabular}{lcccc}
\hline \multirow{2}{*}{ Physical Properties } & \multicolumn{4}{c}{ Types of Coverage ${ }^{\mathrm{a}}$} \\
\cline { 2 - 5 } & $\% \mathrm{~A}$ & $\% \mathrm{~B}$ & $\% \mathrm{C}$ & $\% 0$ \\
\hline Boiling point & 80.0 & 13.3 & 0.0 & 6.7 \\
Melting point & 80.0 & 13.3 & 0.0 & 6.7 \\
Solubility & 73.3 & 26.7 & 0.0 & 0.0 \\
Density & 40.0 & 20.0 & 0.0 & 40.0 \\
Vapor pressure & 0.0 & 20.0 & 0.0 & 80.0 \\
Surface tension & 0.0 & 13.3 & 0.0 & 86.7 \\
Adhesion-cohesion & 0.0 & 0.0 & 0.0 & 100.0 \\
Capilarity & 0.0 & 6.7 & 0.0 & 99.3 \\
Viscosity & 0.0 & 13.3 & 0.0 & 86.7 \\
\hline
\end{tabular}

aNotation: A: Topic is explained, and example(s) are provided; B: Topic is not explained but provides examples; $\mathrm{C}$ : Topic is defined, but examples are not provided; 0: Topic is not covered. ${ }^{\mathrm{b}}$ Form of the meniscus and the drop.

Table 6. Percentual distribution of coverage on biomolecules in textbooks

\begin{tabular}{lcccc}
\hline \multirow{2}{*}{ Biomolecules } & \multicolumn{4}{c}{ Types of Coverage ${ }^{\mathrm{a}}$} \\
\cline { 2 - 5 } & $\% \mathrm{~A}$ & $\% \mathrm{~B}$ & $\% \mathrm{C}$ & $\% 0$ \\
\hline DNA & 86.7 & 0.0 & 0.0 & 13.3 \\
Soap-Micelles & 86.7 & 0.0 & 0.0 & 13.3 \\
Proteins/Enzymes & 86.7 & 6.7 & 0.0 & 6.6 \\
Carbohydrates & 80.0 & 6.7 & 0.0 & 13.3 \\
Cell membranes & 80.0 & 6.7 & 0.0 & 13.3 \\
Cellulose and Starch & 73.3 & 6.7 & 0.0 & 20.0 \\
Drugs-receptors & 66.7 & 20.0 & 0.0 & 13.3 \\
\hline
\end{tabular}

aNotation: A: Topic is explained, and example(s) are provided; B: Topic is not explained but provides examples; $\mathrm{C}$ : Topic is defined, but examples are not provided; 0: Topic is not covered.

Table 7. Percentage distribution of coverage on analytical techniques in textbooks

\begin{tabular}{lcccc}
\hline \multirow{2}{*}{ Analytical Techniques } & \multicolumn{4}{c}{ Types of Coverage $\mathrm{a}^{\mathrm{a}}$} \\
\cline { 2 - 5 } & $\% \mathrm{~A}$ & $\% \mathrm{~B}$ & $\% \mathrm{C}$ & $\% 0$ \\
\hline Infrared & 80.0 & 6.7 & 0.0 & 13.3 \\
NMR & 60.0 & 0.0 & 0.0 & 40.0 \\
Paper Chromatography & 6.7 & 6.7 & 0.0 & 86.6 \\
Chromatography - TLC & 6.7 & 6.7 & 0.0 & 86.6 \\
Column Chromatography & 66.7 & 20.0 & 6.7 & 6.7 \\
Electrophoresis & 66.7 & 0.0 & 0.0 & 33.3
\end{tabular}

${ }^{a}$ Notation: A: Topic is explained, and example(s) are provided; B: Topic is not explained but provides examples; $\mathrm{C}$ : Topic is explained, but examples are not provided; 0 : Topic is not covered. at the chapter that introduces the NMR. The forces of attractions are explained with the providing of examples.

$86.6 \%$ of the books surveyed do not mention the paper chromatography and thin-layer chromatography (TLC) or any relation between them with the intermolecular forces. $86.7 \%$ of the books introduce column chromatography and explain its relationship with the intermolecular forces' influence on the process. However, $20.0 \%$ of the books just present the technique through examples without explaining the importance of intermolecular forces on separating compounds. Finally, only $66.7 \%$ of the books surveyed mention the electrophoresis as an analytical technique related to IMFs.

\section{Other topics related to intermolecular forces}

There are other topics related to intermolecular forces whose mastery is essential to the students (Table 8). For example, the intermolecular forces are crucial in the fiber dyeing process. The survey findings revealed that $53.3 \%$ of the textbooks do not cover that topic; $13.3 \%$ explain the occurrence of intermolecular forces between dyes and fibers and provide examples, and $33.3 \%$ of the books only provide examples but do not give any explanation on the influence of the IMFs on the dyeing process.

Table 8. Percentage distribution of other topics related to IMFs in textbooks

\begin{tabular}{|c|c|c|c|c|}
\hline \multirow{2}{*}{ Topics } & \multicolumn{4}{|c|}{ Types of Coverage $^{\mathrm{a}}$} \\
\hline & $\% \mathrm{~A}$ & $\% \mathrm{~B}$ & $\% \mathrm{C}$ & $\% 0$ \\
\hline Dyes and dyeing & 13.3 & 33.3 & 0.0 & 53.3 \\
\hline Meniscus and drop ${ }^{b}$ & 6.7 & 0.0 & 0.0 & 93.3 \\
\hline Salting-out effect & 0.0 & 0.0 & 0.0 & 100.0 \\
\hline Polymers & 60.0 & 26.7 & 0.0 & 13.3 \\
\hline
\end{tabular}

aNotation: A: Topic is explained, and example(s) are provided; B: Topic is not explained but provides examples; $\mathrm{C}$ : Topic is explained, but examples are not provided; 0: Topic is not covered. ${ }^{\mathrm{b}}$ Meniscus and drop shapes.

The shape of meniscus and drops from different liquids depends on the balance between the cohesive and adhesive forces, strictly related to the IMFs. However, $93.3 \%$ of the textbooks also do not cover that topic. Only $6.7 \%$ of the books surveyed explain the format of meniscus and drops based on IMFs by providing examples.

The salting-out effect is an electrolyte-non-electrolyte interaction whose mastery would help students understand what happens when we add an aqueous saline solution to break the emulsion formed in the liquid-liquid extraction process. Unfortunately, none of the 15 textbooks surveyed covers that content.

Finally, polymers have properties that depend significantly on the forces that act between the chains. $86.7 \%$ of the books cover that topic. $60.0 \%$ of them explain it by providing examples, while $26.7 \%$ only give the examples, failing in the absence of explanation.

The survey of the textbooks identified 212 problems related to at least one of the 31 topics distributed in five categories: i) types; ii) physical properties; iii) biomolecules; iv) analytical techniques; and v) other. However, we highlight that some problems cover more than one topic, then those problems were totalized more than once, increasing the total of problems to 244. Tables 9 and 10 summarize the results of the research. We emphasize that books Clayden ${ }^{24}$ and Hoffmann ${ }^{25}$ were not listed in Table 10 because there are no problems related to intermolecular forces in them. Detailed information about the problems (numbers and pages where they are in each book) is available in the Supporting Information.

Table 9 shows that only 13 of the 15 books analyzed have at least one problem related to intermolecular forces. On the other hand, Table 
Table 9. Number of problems related to imfs in the organic chemistry textbooks

\begin{tabular}{|c|c|c|c|c|c|c|c|c|c|c|c|c|c|c|c|}
\hline \multirow[b]{2}{*}{ Category } & \multirow[b]{2}{*}{ Topics } & \multicolumn{14}{|c|}{ Textbooks } \\
\hline & & 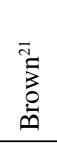 & 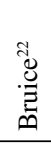 & 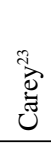 & 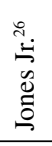 & $\begin{array}{l}\bar{y} \\
\overrightarrow{0} \\
\vec{d}\end{array}$ & 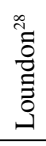 & 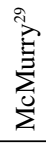 & 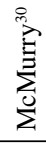 & $\begin{array}{l}\overline{\mathrm{g}} \\
\bar{E} \\
\bar{n}\end{array}$ & 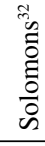 & $\begin{array}{l}\frac{\pi}{0} \\
\frac{0}{0} \\
\frac{3}{\infty} \\
\text { is }\end{array}$ & 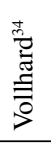 & 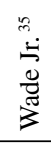 & స్ّ \\
\hline Type & Identification of interaction & 02 & 01 & 03 & 02 & 01 & 01 & & & 08 & & & & 02 & 20 \\
\hline \multirow[t]{10}{*}{ Physical proprieties } & Boiling point & 15 & 08 & 06 & 01 & 04 & 09 & & & 25 & 06 & 01 & 03 & 08 & 86 \\
\hline & Melting point & 03 & 05 & 01 & 01 & 04 & 03 & 01 & 01 & 08 & & & & & 27 \\
\hline & Solubility & 13 & 09 & 02 & 01 & 02 & 19 & 01 & 01 & 20 & 06 & 01 & 03 & 07 & 85 \\
\hline & Density & 03 & 01 & & & & 01 & & & & & & & & 05 \\
\hline & Vapor pressure & & & & & & & & & & & & & & \\
\hline & Surface tension & & & & & & & & & & & & & & \\
\hline & Adhesion-cohesion & & & & & & & & & & & & & & \\
\hline & Capilarity & & & & & & & & & & & & & & \\
\hline & Viscosity & & & & & & & & & & & & & & \\
\hline & Physical state & & & & & & & & & 01 & & & & & 01 \\
\hline \multirow[t]{8}{*}{ Biomolecules } & Cellulose and Starch & & & & & & & & & & & & & & \\
\hline & Carbohydrates & & & & & & & & & & & & & & \\
\hline & Fatty acids-Soap-Micelles & 04 & & & & & & & & 03 & & & 01 & & 08 \\
\hline & Lipids & 01 & & & & & & & & & & & & & 01 \\
\hline & Cell membranes & 01 & & & & & & & & & & & & & 01 \\
\hline & DNA & 04 & & & & & & 01 & 01 & & & & & & 06 \\
\hline & Proteins-Enzymes & 03 & 01 & & & & & & & & & & & & 04 \\
\hline & Drugs-receptors & & & & & & & & & & & & & & \\
\hline
\end{tabular}

\begin{tabular}{|c|c|c|c|c|c|c|c|c|c|c|c|c|c|c|c|}
\hline \multirow[t]{6}{*}{ An. Tech. } & Infrared & & & & & & & & & & & & & & \\
\hline & NMR & & & & & & & & & & & & & & \\
\hline & Paper chromatography & & & & & & & & & & & & & & \\
\hline & Chromatography - TLC & & & & & & & & & & & & & & \\
\hline & Chromatography - Column & & & & & & & & & & & & & & \\
\hline & Electrophoresis & & & & & & & & & & & & & & \\
\hline \multirow[t]{6}{*}{ Other } & Graphite & & & & & & & & & & & & & & \\
\hline & Crown ether & & & & & & & & & & & & & & \\
\hline & Meniscus and drop format & & & & & & & & & & & & & & \\
\hline & Dyes and dyeing & & & & & & & & & & & & & & \\
\hline & Salting-out effect & & & & & & & & & & & & & & \\
\hline & Polymers & & & & & & & & & & & & & & \\
\hline \multicolumn{2}{|c|}{ Total of the problems on IMFs } & 44 & 21 & 09 & 04 & 11 & 32 & 03 & 03 & 51 & 12 & 01 & 06 & 15 & $212 *$ \\
\hline \multicolumn{2}{|c|}{$\%$ of the problems on IMFs } & 3.0 & 1.1 & 0.6 & 0.3 & 0.6 & 1.7 & 0.2 & 0.2 & 2.4 & 0.9 & 0.0 & 0.4 & 1.1 & \\
\hline
\end{tabular}

Table 10. Number of problems per category of IMFs in Organic Chemistry textbooks surveyed

\begin{tabular}{lcc}
\hline \multirow{2}{*}{ Category } & \multicolumn{2}{c}{ Number of Problems } \\
\cline { 2 - 3 } & Total $^{\mathrm{b}}$ & $\%$ \\
\hline Type & 20 & 8.2 \\
Physical properties & 204 & 83.6 \\
Biomolecules & 20 & 8.2 \\
Anal. Techniques & 00 & 0.0 \\
Other $^{\mathrm{a}}$ & 00 & 0.0 \\
\hline Total & 244 & 100.0
\end{tabular}

aOther: Graphite, crown ether, meniscus and drop shape, dyes and dyeing, salting-out effect, and polymers. ${ }^{b}$ There were problems related to more than one topic.
10 reveals that the problems cover only three of the five categories surveyed. The vast majority of problems $(83.6 \%)$ are related to the organic compounds' physical properties. However, no problem discussed the importance of intermolecular forces on the physical properties such as vapor pressure, surface tension, adhesion-cohesion, capillarity, viscosity, and physical state of the organic compounds. Only $8.2 \%$ of the problems aim to identify the type of intermolecular force acting between species. $8.2 \%$ is regarding biomolecules like fatty acids, soap-micelles, lipids, cell membranes, DNA, proteins, and enzymes. Nevertheless, none of the 244 problems addresses the intermolecular forces' influence on graphite's structure, crownether, meniscus and drop shapes, dyes and dyeing, salting-out effect polymers.

Although analytical techniques (infrared, NMR, chromatography, electrophoresis), and other molecules and phenomena (graphite, crow 
ether, dyeing, salting-out effect, and polymers) are covered in books by relating them to IMFs (Tables 7 and 8), none of the 244 problems addresses those categories.

The fifteen books analyzed have a total of 20,684 problems $(1,378.9$ on average). However, only $212(0.73 \%)$ of them are related to intermolecular forces. This low percentage value reveals the little attention that organic chemistry textbooks give to this theme.

\section{CONCLUSIONS}

This paper analyzes fifteen organic textbooks most commonly used at Brazilian universities to find out how the books address the intermolecular forces and related topics. We found that all books cover the theme, but none has a specific chapter on IMFs. Regarding the problems associated with IMFs, the subject is usually spread over several chapters, varying from one up to twelve chapters. Thirteen of the fifteen books have at least one problem regarding intermolecular forces. However, the vast majority of problems $(83.6 \%)$ are related to the organic compounds' physical properties. $8.2 \%$ are associated with identifying intermolecular forces between chemical species, and $8.2 \%$ are regarding the biomolecules. The absence of problems about the relationship between the intermolecular forces and analytical techniques, organic molecules' structures like graphite and polymers, and important chemical phenomena such as the salting-out effect may negatively impact the students' learning. As textbooks are a powerful and widely used medium for information transmission, we believe that intermolecular forces' coverage is inadequate and needs to have more significant editors' attention in the next editions of the organic chemistry textbooks.

\section{SUPPLEMENTARY MATERIAL}

All problems surveyed (and its respective pages) in each book are freely available on the tables $1 \mathrm{~S}-15 \mathrm{~S}$ in http://quimicanova.sbq. org.br, in PDF file.

\section{ACKNOWLEDGMENT}

We appreciate all Brazilian and French professors who answered the electronic form. Also, we appreciate the designer Ulisses Silva de Sousa for making the graphical abstracts.

\section{NOTES AND REFERENCES}

1. Schmidt, H.; Kaufmann, B.; Treagust, D. F.; Chem. Educ. Res. Pract 2009, 10, 265.

2. Torres, N.; Landau, L.; Bamonte, E.; Di Giacomo, M.; Erausquin, P.; Fornaso, C.; Mastrángelo, M.; Monteserin, H.; Educ. Quim. 2005, 16 , 129.

3. Gilbert, J. K.; de Jong, O.; Justi, R.; Treagust, D. F.; van Driel, J. H.; Chemical Education: Towards Research Based Practice, Kluwer Academic Publishers: Dordrecht, 2002.

4. Harrison, A. G.; Treagust, D. F.; Particles and Matter: Problems in Learning About the Submicroscopic World, Logos Verlag Berlin: Berlin, 2006.

5. Gabel, D. L.; Samuel, K. V.; Hunn, D.; J. Chem. Educ. 1987, 64, 695.

6. Peterson, R. F.; Treagust, D. F.; Garnett, P.; J. Res. Sci. Teach. 1989, 26, 301.

7. Griffths, A. K.; Preston, K. R.; J. Res. Sci. Teach. 1992, 29, 611.
8. Osborne, R. J.; Crosgrove, M. M.; J. Res. Sci. Teach. 1983, $20,825$.

9. Cooper, M. M.; Williams, L. C.; Underwood, S. M.; J. Chem. Educ. 2015, 92, 1288 .

10. Williams, L. C.; Underwood, S. M.; Klymkowsky, M. W.; Cooper, M. M.; J. Chem. Educ. 2015, 92, 1979.

11. Widarti, H. R.; Marfuaf, S.; Retnosar, R.; Unnes Sci. Educ. J. 2019, 8, 46.

12. Tarhan, L.; Kayali, A. H.; Urek, O. R.; Acar, C.; Research in Science Education 2008, 38, 285

13. Ogden, M.; J. Chem. Educ. 2017, 94, 897.

14. Luxford, C. J.; Bretz, S. L.; J. Chem. Educ. 2014, 91, 312.

15. Jasien, P. G.; J. Chem. Educ. 2008, 85, 1222.

16. Nakhleh, M. B.; J. Chem. Educ. 1992, 69, 191.

17. Peterson, R. F.; Treagust, D. F.; J. Chem. Educ. 1989, 66, 459.

18. Smith, B. D.; Jacobs, D. C.; J. Chem. Educ. 2003, 80, 99.

19. Brazilian universities: Universidade Federal do Ceará, Universidade Estadual de Campinas, Faculdade de Campinas, Universidade Federal do Maranhão, Universidade Federal do Rio Grande do Norte, Universidade Federal de Pernambuco, Universidade Federal da Bahia, Universidade Federal de Alagoas, Universidade Federal do Mato Grosso do Sul, Universidade Estadual do Rio de Janeiro, Universidade Estadual de São Paulo, Universidade de São Paulo, Universidade Federal do Rio de Janeiro, Universidade Pontifícia Católica do Rio de Janeiro, Universidade Federal de Viçosa, Universidade de São Paulo - São Carlos, Universidade Federal de Santa Maria, Universidade Federal de Lavras, Universidade Estadual de Campinas, Universidade Federal do Norte Fluminense, Universidade Federal do Amazonas, Universidade Federal do Acre, Universidade Federal de Uberlândia, Universidade Federal de Santa Catarina, Universidade Estadual de Londrina.

20. French universities: CY Cergy Paris Université, École d'ingénieur en Chimie Montpellier, Université Montpellier, University of Lyon, Université de Poitiers, Université de Caen Normandie.

21. Brown, W. H.; Iverson, B. L.; Anslyn, E.; Foote, C. S.; Organic Chemistry, $6^{\text {th }}$ ed.; Cengage Learning: Boston, 2012.

22. Bruice, P. Y.; Organic Chemistry, $7^{\text {th }}$ ed.; Pearson: New York, 2014.

23. Carey, F.; Giuliano, R.; Allison, N. T.; Bane, S. L.; Organic Chemistry, $7^{\text {th }}$ ed.; McGraw-Hill: New York, 2008.

24. Clayden, J.; Warren, S.; Greeves, N; Wothers, P.; Organic Chemistry, $1^{\text {st }}$ ed.; Oxford University Press Inc.: New York, 2001.

25. Hoffmann, R. V.; Organic Chemistry. An Intermediate, $2^{\text {nd }}$ ed.; Wiley: Hoboken, 2004.

26. Jones, M.; Fleming, S. A.; Organic Chemistry, $4^{\text {th }}$ ed.; W. W. Norton \& Company: New York, 2010.

27. Klein, D.; Organic Chemistry, $3^{\text {rd }}$ ed.; Wiley: Hoboken, 2016.

28. London, M.; Parise, J. Organic Chemistry, $6^{\text {th }}$ ed.; W. H. Freeman and Company: New York, 2016.

29. McMurry, J. E.; Organic Chemistry, $8^{\text {th }}$ ed.; Cengage Learning: Boston, 2012.

30. McMurry, J. E.; Organic Chemistry Biological Applications, $2^{\text {nd }}$ ed.; Cengage Learning: Boston, 2011.

31. Smith, J. G.; Organic Chemistry, $3^{\text {rd }}$ ed.; McGraw-Hill: New York, 2008.

32. Solomons, T. W. G.; Fryhle, C. B.; Snyder, S. A.; Organic Chemistry, $10^{\text {th }}$ ed.; Wiley: Hoboken, 2011.

33. Fabirkiewicz, A. M.; Stowell, J. C.; Intermediate Organic Chemistry, $3^{\text {rd }}$ ed.; Wiley: Hoboken, 2016.

34. Vollhardt, K. Peter C.; Organic Chemistry: Structure and Function, $6^{\text {th }}$ ed.; W. H. Freeman and Company: New York, 2011.

35. Wade, L. G.; Simek, J. W.; Organic Chemistry, $6^{\text {th }}$ ed.; Pearson: New York, 2006. 